\author{
JURNAL PENJAMINAN MUTU \\ LEMBAGA PENJAMINAN MUTU \\ INSTITUT HINDU DHARMA NEGERI \\ DENPASAR
}

Volume 5 Nomor 2 Agustus 2019

ISSN : 2407-912X (Cetak)

ISSN : 2548-3110 (Online)

http://ejournal.ihdn.ac.id/index.php/JPM

\title{
IMPROVING THE QUALITY OF TELEVISION MEDIA BROADCASTS IN TACKLING FREE SEX AMONG TEENS
}

\author{
Oleh \\ Ida Ayu Tary Puspa, I Gede Agus Krisna Warmayana, I Ketut Mardika*, \\ Ni Putu Evie Sintya Wati \\ Institut Hindu Dharma Negeri Denpasar, Bali, Indonesia \\ *mardika@ihdn.ac.id
}

diterima 09 Juli 2019, direvisi 11 Agustus 2019, diterbitkan 31 Agustus 2019

\begin{abstract}
Television media is a means of conveying information and communication to many people or society. The knowledge can be accepted by society quickly. Television Media is a means or tool used as information source, education and entertainment. Teenager is a transition period from children to adults which are 11-24 years old. Adolescence is known for a time full of flaming, indecision, and a great sense of curiosity so need extra control from all of parties, especially their parents and educators. Teenagers today are much influenced by promiscuity such as fee sex. Television media has a variety of programs show that interesting to children and teenagers have a variety of impacts in both positive and negative life especially for teenagers who use television media. Today television shows much of violence contents and promiscuity affect the viewing teenagers and the show intersect with the values and social norms in society. Here are some of the television media roles in tackling free sex in among teenagers, they are: Television is as society education media and used of television in teenager's life. Television media can be used as one of popular education media of people. Television media can act as an education media by watching the educative show for society. The show that educates be followed by teenagers need getting assisted parents which is able to direct the educative show for their children. The roles of parents, society, education institution have important roles in giving education and directiving so education about sex is not taboo to be learned.Television attracts good interest to adult especially to children and teenagers who like to watch television because it interesting shows and programs and how to present them in a fun way. Television is used by teenagers as entertainment and knowledge media where teenagers can get information quickly and easily.
\end{abstract}

Keywords: Improving The Quality; Television Media Broadcasts; Free Sex; Teens 


\section{INTRODUCTION}

The mass media has become an inseparable part of society. Every day we interact intentionally, or unintentionally with the media. According to the Association for Education and Communication Technology (AECT) defines the media, namely as a form used for a process of information distribution. The mass media has become a new force capable of influencing human life in the modern age as it is today. How strong the role of mass media today has been able to take over social functions, dominate life and even influence the emotions and the reasoning power of humans in everyday life. One type of mass media that is the majority in every home is television. Television has audiovisual properties and has many functions including information functions, educational functions, and entertainment functions.

Television media is a means of conveying information and communication to many people or society. The knowledge can be accepted by society quickly. The existance of television media facilities the society in overcoming the existing difficulties.

The existence of television has been considered a double-edged knife that has positive and negative impacts for its viewers. In addition to providing broadcasts in accordance with the function of the media, namely as a medium of information, education, entertainment, and social control. At the same time many people became concerned about the negative effects of television broadcasts, including pornography, violence and the interests of institutions that had economic, political and cultural interests (Ahmadi, 2007).

The discovery of television began in 1873 a telegram operator found that light affects the electrical resistance of selenium. At that time has not been found electrical components of vacuum tubes (Cathode Ray Tube). Electronic television was somewhat stunted in the years, largely because of the cheaper and resilient mechanical television (Ahmadi, 2007).
Television has function as entertainment, information, education, control and social adhesives media. Broadcasting institution have clearly set this up considering the influence of the television media is very large for society, especially children and teenagers (Darmawan, 2011). Broadcasting institution has a broadcasting rules of conduct guidelines for limiting and supervising television stations in programming.

One of the factors of the shows that are not good or inappropriate is violence. Violent programs are widely used as a profitable commodity in the entertainment world. When examined based on indicators of the quality of the soap opera / film program, the results of the May-June 2016 survey period by KPI show the aspects of 'shaping the character, identity, and identity of Indonesian people who are pious and believing' shows the most 4 low, which is 2.39. In addition, soap opera stories are considered irrelevant and the content of violence is still considered to be there. Even though at the time of broadcast when families gather many families watch soap operas / films simultaneously or commonly called prime time. Until now, fewer television stations pay attention to the educational element for their viewers, shows that have educational elements continue to be reduced, displaced by less educational shows.

Whereas television is a media that provides information and knowledge through audio-visual media, which incidentally is a media that can be easily absorbed by all groups, and the values embedded through television will give a distinctive impression on the viewer and have an influence on one's attitude patterns The issue of broadcasting that attracts the attention and attention of the public is a matter of television content that is less child-friendly. This is important because as the most consumed media for children, television should be able to free itself from all forms of violence. Television is an important medium for children to internalize certain social values in society. 


\section{DISCUSSION}

Teenagers today are much affected by promiscuity such as free sex. Television media has a variety of show programs that attract children and teenagers have a variety of impacts in both positive and negative life, especially for teenagers who use television media. Television show today show of violence and promiscuity affect the viewing teenagers and show that intersect with values and social norms in society (Jalaluddin, 2005).

Based on the classification of broadcast content classification can be watched that there has been an arrangement of events by children and teenagers. This classification is aimed at not having a negative impact on viewers. When children or teenagers watch televitsion should remain in accompanied by parents to control the show that were witnessed. The show on the content of stories or discussions about deviant sexual behavior, homosexuality, and lesbian, commercial sex worker, and presenting recording of the individual or collative by fear and trauma to public (Regulation of KPI no. 032007 year Chapter VII) [4]. Here is some roles of television media in tacking free sex among teenagers, they are:

\subsection{Television As Society Education Media}

Television by broadcasting law has a very good fuction because it is used as informastion and lighting media, as education and entertaiment media, as a media to strengthen idology, politics, economy, socio-culture, as defense and security media.

Education in teenager is very important done because eucation has some important unsures are first, education process is implemented to reliaze certain expectation. Hope will lead the education process to succeed in making it happen (Komisi Penyiaran Indonesia, 2009). Second, the entire education process is done deliberately and planned to reliaze the purpose of education. Third, the implementing of education involves various unsure which all these unsure are integral. Fourth, education is an ongoing, systematic, and sustainable activity. Law no. 202003 year about the National Education System, is a conscious and planned effort to creat an atmosphere of learning so that learners are actively developing their potential. Education is a field that has broad meaning not only in schools or educational institutions related to learning, but the whole process of behavior formation and lifestyle of society in general.

Television media can be used as one of the popular education media of society.Television media can act as an educational media by watching educstion show for society. The show that educate to be followed by teenagers need to get assisted parents who can direct educational show to children. The role of prents, society, and education institutions has an important role in providing education and direction so that education about to sex is not considered taboo to be learned (Pasek, 2006).

Parents have a role besides taking care of their children, they also carry out social activities such as working, carrying out social activities in their environment and so on. A father is the head of the family who also earns a living for his family. The role of the mother is certainly very urgent in the family, especially childcare. But the role of mothers is now beginning to transform as the meaning shifts, women are not only dealing with household problems, many of them have working children. So that the role to care for children is less than the maximum due to busy parents. The researchers also met at Padukuhan Sanggrahan, family economic factors make care for children less than optimal. The influence of television as a medium of entertainment that can affect one's attitudes and behavior also occurs. Based on 
observations, researchers found that children already knew the courtship of soap operas that were on television, it was shown by one of the children showing photos of his girlfriend to researchers in tutoring activities. This phenomenon indicates that when children watch television without guidance and assistance from other parties such as parents, the child will immediately construct what is on television as a good fit and can be imitated. The influence of other television also seems to start sometimes recognize stars in soap operas. Children talk a lot about behavior and artists in soap operas, even though it's not necessarily a good thing for their age. Amid the flood of messages on the television, it needs to be responded critically. The presence of television media literacy is needed. Parents who have a high understanding of media literacy knowledge and applications may not cause problems, because for those with high literacy they are able to sort and choose television shows that are appropriate for their child's age, but for parents who understand low literacy is not impossible cause problems. This happens because parents are not selective in choosing shows that are suitable for children. Even though television shows that are not in accordance with the age of the child, it is not impossible to form negative characters. This is where parents have an important role in introducing basic literacy to children. Therefore, the role of parents to protect children when watching television is highly expected so that children are free from the negative effects of television broadcasting. The family has an important role in the development of media literacy. Parents are no longer the sole or primary reference in shaping children's behavior, but parents have competitors who are also favored by children, namely television. Television became one of the environmental elements that helped shape the personality and behavior of children Television present sounds and pictures that are interesting and easily understood by the society. Television show is very interesting especially for children and teenagers. Television presents a lot of interesting and new things, where the actors in it dominant teenagers. The show that many abusive educators, disrepectful students in dress, short skirts clothes issued, colored hair and lifestyle teenagers in schools that regardless of rules and dicipline. Implementing of self-discipline or character formation in children will be difficult if education has been used as an arena of lifestyle implementation without self discipline.

Parents need to direct their children to watch an educative program of show, this is one of the efforts of parents to provide education in the family environment. Parents areare the closest educators to children and teenager. The show programs that have an educative value that has a positive impact on society including children teenager include:

First, news program shows that present the lastest information and lastest developments in the society. Watchig news shows is tantamount to finding out about what's happening at the local, national and international levels. Reading the development of situations and information will make the insight and intelligence a personis getting better. The news presented can be political, economic, social, religious, cultural, and sports news. Thiss news show can be formatted again to beinteresting in the form of discussion, dialogue and talk show (Suja, 2000). Show of news formatted in the form of enertainment and have a bad impact need to watch infotaimebt need to be limited because it is less useful and give a bad influence in its development. 
Second, show of motivational programs that can be provide inspiration and new spirit. Stasun Television has a motivational program that is able to provide new light and ideas in living everyday life. This motivational show provides an impetus to be passoonate about doing activities and providing solutions in the face of adversity in life. The existence of this motivation program is able to give strength to expression and explore the ability that exist in self, as shown in Dewata TV in Bion and Metro TV event in Mario Teguh and Kick Andy.

Third, show of adventure programs and encyclopedias capable of providing curiosity and curious enough to be ble to find out more.Watching television programs that are adventurrous and exploring to various regions greatly add knowledge to the audience. the teenagers are very good when presented impressions that are adveturous to open up insights and motivate himself to go further. Impressions in the form of exploration, cultural tourism and entrepreneurship can provide a positive impetus for those who witnessed.

Fourth, religious shows that teach about religious teachings. Religious programs can be seen in the morning. Religious display program is good to provide education about religious teachings. The better the way of delivery the more interesting for the audience. As presented by MNC TV on Sunday morning at 08.00, entitled Spiritual Guidance of Hinduism. This show presents different topics in each of its broadcasts that present speakers who master the topics discussed at the time and also couple with the discussion.

Fifth, a sports show that provides knowledge of how important exercise is to maintain health. RCTI and ANTV television stations are two of the existing television station that often feature live sports events such as football, boxing, and badminton matches at local, national and international levels. A live sports event is one of the educational shows for the audience. Moreover, if the game presents national teams that compete. Impressions like this will foster the spirit of nationalism of a citizen.

\subsection{Utilization of Television in Teenager's life}

Television today have grown very rapidly, from simple television to most modern.Television has many benefits for society especially for teenagers. The existence of television can facilitate teenager get information for ease in education and increase knowledge.

In accordance with the regulation of KPI number 022007 year on Standard Program Broadcast Article 4 reads Broadcasting as a mass communication activity has a function as a medium of information, education, healty entertainment control and social adhesive.

Cognitive benefits are those related to science or information and skills. The show it able to provide knowledge and information that has no been obtained by teenagers. Able to develop insight and mindset of teenager in facing a condition or phenomenon. The second benefits is affective benefits, which are related to attitudes and emotions. Occasions that usually bring there affective benefits are events that encourage viewers to have social sensitivity, human cares, and so on. Emotional and mind-blogging events to train the teenager's sensivity and teach how to analyze and respond to problems in certain situations and conditions teenagers may encounter in their lives.

The third benefit is psychomotor benefuts, which are related to positive actions and behaviours. This event can be seen from the movies, soap operas, drama and other event on condicion that it does not conflict with the norms in Indonesia or damage morals in 
Indonesia or damage morals in children and teenagers.

Television attracts good interest to adults especially to children and teenager who like to watch television because of its exiting shows or programs and how to presesnt them in a fun way. Television is used by teenagers as entertaiment and knowledge media where teenager can get information quickly and easily. Television is used to fill the spare time after a day of activity because it can be used without spwnding a large fee.

Television media plays a role in transforming ssimple teenager character into a luxurious lifestyle. Whereas the eastern people live modestly, but through teenagers television turns into people with a new lifestyle, full of luxuries and pleasure that is biased with dreams and imagination. The lifestyle of the city people displayed on television with its luxury attrascts teenagers under the force of passionsand biased desires, teenager as individuals are manipulated, constructed, destroyed so as to lose their personality. Over time teenager behaviour becomes spontaneous and creative change. The result of this is slowly getting into compettion, envy, and hostility.

Television media is a means that can penetrate space and time, giving a tremendous change effect in teenager. Symptoms of this change interrupt the ability of teenager in understanding and mastering the environment. Character and moral changes in teenager is one of impacts of the progress of television media. Often watching television a child dare to flight his parents, disobeying and doing brash because they do not want to be disturbed watching the event he like.

Television programs start from movies, music, talk, shows, infotainment, and more ads that show the beauty of a woman's body. Some of the shows that are displayed at night are related to sex and domestic life. Women are displayed with vulgar and manipulated as perpetrators of pornography. Women display violations of social rules that are unacceptable to society. Television footage shows publicly acceptable sexual acts if they are still in a very private area.

Pornographic shows are very influential in teenager. There was a lot of sexual behavior outside of marriage and harassment of women committed by teenagers from the stimulation of television media. Television media that broadcast programs with sex and porn spice is harassment of women and moral destruction in society, especially teenagers (Utama, 2004).

Sex and pornography on television have dragged teenager to pornography and harassment behavior toward female peers. Sexuality and pornography for some people is a land to earn sustenance, where it is done under the pretext of art and beauty as a woman's body that is often displayed is private property that should be taken care so there is no more abuse against women.

Teenager creativity will follow nature and their social movements. Seeing things new then teenagers will be motivated to be more creative and innovative. Television media often show rape committed to minors, a teenager steals, teenager who likes to flight, teenagers who commit suicide by breaking up with their girlfriends, and the last "smack down" show that many children watched. Violent shows such as need to be avoided from children and teenagers so that the emerging creativity is not creativity in the negative direction.

\section{CONCLUSION}

Television media plays a role in influencing teenager's behavior. The existence of television with various functions and ways of utilization has the potential to increase free sex behavior among teenager. 
Television media is used as a play station makes children and teenagers are lazier to learn. Utilization as an entertainment media provides a less positive understanding when there is no mentoring to teenagers. Television media has a major impact on teenager's life such as social change, change of mindset/ way of thinking teenager in responding something, lifestyle change, behavior change and cultural change in teenager. Teenagers need to get the television media so that the existence of television media can have a positive impact in teenager's life.

Parental media literacy in this study can be categorized as basic level media literacy. Parents belong to the heavy audience category with a frequency of watching between 2-5 hours a day and are dominated for entertainment purposes. The ability of parents to critically analyze information is still limited. Knowledge about the industry and how press performance is still available. Assistance provided by parents to children in watching television is still not consistent or only in certain conditions, as for the methods used, 1) explaining the existing shows while accompanying them when watching as lovingly as possible on shows that are considered to have a negative effect, 2) asking children to switch to broadcasts other if there are inappropriate shows, 3) putting the television in an easy place to conduct surveillance, but that has not been applied by all parents, 4) limiting television viewing, but the application is not working. community learning hours. While the inhibiting factor is the busyness of parents so that the assistance is not consistent and knowledge of media literacy

\section{REFERENCES}

Ahmadi, A. (2007). Psikologi Sosial. Jakarta: Rineka Cipta

Darmawan. (2011). Fungsi Televisi Lokal dalam Transformasi Nilai-Nilai Agama Hindu dan Budaya Bali. Denpasar: UNHI

Jalaluddin, H. (2005). Psikologi Agama Memahami Prilaku Keagamaan dengan Mengaplikasikan PrinsipPrinsip Psikolog. Jakarta: PT. Rajagrafindo Persada

Komisi Penyiaran Indonesia. (2009). Pedoman Prilaku Penyiaran \& Standar Program Siaran. Denpasar: Sekretariat KPID Bali

Pasek, I K. L. S. (2006). Peranan Orang Tua dalam Membina Moral Remaja di Desa Pakraman Panglipuran Kelurahan Kubu Kecamatan Bangli Kabupaten Bangli. Denpasar: IHDN

Suja. I W. (2000). Titik Temu IPTEK dan Agama Hindu, Tafsir Ilmiah Ajaran Veda. Jakarta: PT Pustaka Manikgeni

Utama, I W. B. (2004). Seksualitas dalam Brahma Widya (Teologi) dan Tradisi Hindu di Bali. Denpasar: UNHI 